\title{
Huma Betang Cultural Influence in Moderating Budgetary Participation in Budgetary Slack
}

\author{
Gayatri $^{1}$, Theresia Octaviani ${ }^{2}$ \\ Accounting Program, Faculty of Economic and Business, Udayana University \\ Bali, Indonesia \\ gayatriestibra@gmail.com
}

\begin{abstract}
The purpose of this research is to find out the influence of budgetary participation and huma betang cultural moderation on budgetary slack. The population consists of 28 Palangkaraya's Regional Apparatus Working Units, Central Kalimantan Province. Proportionate random sampling is used as the sample selection technique. Furthermore, data collection technique is conducted through the questionnaires distribution to 100 respondents. As for the data analysis techniques, simple linear regression analysis is used to test the first hypothesis, and moderation regression analysis with the absolute difference test is employed to test the second hypothesis. The results show that budgetary participation has a positive effect on budgetary slack and the culture of huma betang moderates the relationship of budgetary participation toward budgetary slack. Hence, the suggestion for the next research is that it should be performed in all local government budgeting process.
\end{abstract}

Keywords: participation, budgetary slack, huma betang.

\section{INTRODUCTION}

The government budget serves as a benchmark whether or not any activity undertaken by each Regional Apparatus Working Units (SKPD) is successful. Bottom-up, the pattern by involving all existing SKPD, is used for budget preparation at Palangkaraya City Government of Central Kalimantan province. Budget preparation sometimes influenced by the individual behavior which tends to easily realize the budget by lowering revenue and rising costs from the organization best potential or budgetary slack (Govindarajan, 1986; Young, 1985; Anthony and Govindarajan, 1998). It is caused by contractual relationships between principal which is represented by the Head of Region and agent which is represented by the Head of SKPD (Jensen and Meckling, 1976; Kencana, 2010). The principal is motivated to increase the utility of the budget while the agent is motivated by the personal interest of improving his future career. To resolve the conflict between principal and agent, the existence of participation in the budgeting process becomes necessary (Onsi, 1973, Merchant, 1981; Dunk, 1993; Hansen and Mowen, 2013). On the other side, other studies have found that participation in the budgeting process has led to the budgetary slack performance by agents (Lowe and Shaw, 1968; Young, 1985; Lukka, 1988). To overcome the explained contradiction, it is necessary to have contingency factor as a budgetary slack predictor (Govindarajan, 1986) that is local culture (Robbin and Judge, 2008; Hofstede, 2011) of Dayak huma betang. The culture of Huma betang is reflected in the 2013-1018 vision and mission of Palangkaraya City Government. The cultural philosophy of huma betang which is held and inherited intensively, fundamentally, firmly and widely constitutes as the strong local culture. The stronger the local culture is, the greater loyalty of organization member is (Hoefstede, 2011).

Huma betang comes from Ngaju Language. Huma means house and betang means long or big. Huma Betang means longhouse or big house (Wahidin, 2001). Huma betang 30-150 meters long, 10-30 meters wide, 3-4 meters above the ground, inhabited by 10-40 households or 100200 people. Huma betang only has one door, and the stairs (called as hejan or hejot) is located on the front of the house. The huma betang residents consist of a wide variety of cultures, sub-ethnics, and religions headed by the head of betang that is the main character of all the residents (Tjilik Riwut, 2007). The life of huma betang is guided under one particular value order that applies to all and accepted by all with full awareness (Kusni Sulang, 2011). The ease of interaction between huma betang residents will strengthen the sense of brotherhood, solidarity and togetherness and unity.

The cultural philosophy of huma betang is chosen to be a vision by the Palangkaraya City Government for the realization of a cultured, harmonious, dynamic, and peaceful society. Palangkaraya City Government wants to build a country even though it consists of various religions, groups and ethnic (Abubakar, 2016) through the behavior of life that uphold honesty, equality, togetherness, tolerance and law-abiding (Governor of Central Kalimantan, 2008). To achieve this, good and clean governance should be implemented through participation in budgeting. So the first problem asked is whether budget participation affects 
budgetary slack. And the second problem is whether the huma betang culture is moderating the influence of participative budgeting on budgetary slack.

\section{RESEARCH METHOD}

The research population is all echelon of Regional Apparatus Working Units (SKPD) of Palangkaraya City Government of Central Kalimantan Province which consists of 792 people in over 28 SKPD. Secondary data used in the form of Central Kalimantan Municipal Government Budget Report from 2008 to 2016. The sample selection technique uses proportionate stratified random sampling, grouped in a certain level based on echelon. The samples are the 100 respondents. The independent variable in this study is budget participation (X1), the dependent variable is budgetary slack (Y), and moderation variable is huma betang culture (X2). Data collection technique uses a survey method through the distribution of questionnaires towards the respondents (Sugiyono, 2011). Questionnaires on budgetary participation use six statements, budgetary slack use six statements and huma betang culture uses eight statements. Confirmatory factor analysis is used in X2 because there are some invalid statement items so that three statements are rejected because the value of the standardized coefficient is relatively small. Measurement of each statement in the questionnaire uses the five-point Likert scale as follows: score 1 for strongly disagree, score 2 for disagree, score 3 for hesitate, score 4 for agree and score 5 for strongly agree. The classical assumption test is performed by normality test with the kolmogorov-smirnov, the multicollinearity test is performed by the variance inflation factor, and heteroscedasticity test is performed by using glejser test. Analysis data uses simple linear regression analysis technique to examine the effect of budgetary participation on budgetary slack and moderation regression analysis technique with absolute difference test to test the ability of huma betang culture in moderating budget participation relationship with budgetary slack. The significance level used is 5\% (Ghozali, 2011). This study is limited to the planning and budget preparation process.

\section{RESULTS AND ANALYSIS}

All model passes from the classical assumption test. Based on table 1, regarding the test for the first hypothesis, it is noted that the regression equation $\mathrm{Y}=1.858+0.378$ $\mathrm{X} 1+\mathrm{e}$ is formed. With result $\mathrm{R}^{2}=0,432$ or $43,2 \%$ the budgetary slack variation can be explained from budget participation with $\mathrm{F}$ count equal to 72,376 with $\mathrm{F}$ Sig = $0,000<0,05$ so this model is feasible to be used. About the test for the first hypothesis which is budget participation has a positive effect on budgetary slack is indicated by beta coefficient value of 0.378 with p-value of $0.000<0.05$, and it has proven. Employee participation in budgeting will increase budgetary slack for individual interests to ease the target. The higher the participation of employees in preparing the budget is, the more freely employees in determining what they want to achieve is. Budgetary slack is performed to create an impression that the SKPD will look good if the budget can be achieved. These results support Lowe and Shaw's research (1968), Merchant (1981), Young (1985), Lukka (1988), Siegel and Marconi (1989), Yuwono (1999), Yuhertiana (2004), Hafsah (2005), Falikhatun 2007), Ikhsan and Ane (2007), Sudarba (2010), Andriyani and Hidayati (2010), Nasution (2011), Reysa (2011).

Regarding the test for the second hypothesis, it is noted that regression equation $\mathrm{Y}=3,399+0,266 \mathrm{ZX} 1+0,156$ $\mathrm{ZX} 2+0,088 \mathrm{Abs}(\mathrm{ZX} 1-\mathrm{ZX} 2)+\mathrm{e}$ is formed. It is proved by the value of $R^{2}$ of 0.575 or $57.5 \%$ of the budgetary slack variation can be explained by the variation of budget participation, the huma betang culture and the interaction between the two. F value counts as 41,956 with F Sig of $0,000<0,05$ so this model is feasible to be used. The second hypothesis that huma betang culture moderating the relationship of budget participation to budgetary slack is proved by beta coefficient value equal to 0,088 with $\mathrm{p}$-value equal to $0,017<0,05$. Better cultures can moderate the influence of the relationship between budgetary participation and budgetary slack. The huma betang culture which is full of harmony, dynamic, and peace which embodied the participation of budget preparation will decrease the desire of Palangkaraya City Government officials to do budgetary slack. These results support the research of Maskun (2008), Reysa (2011), and Sandrya (2013)

TABLE 1

THE RESULT OF REGRESSION ANALYSIS

\begin{tabular}{lcccc}
\hline \multicolumn{1}{c}{ Model } & Variable & $\begin{array}{c}\text { Unstandardized } \\
\text { Coefficients }\end{array}$ & Value t & $\begin{array}{c}\text { Significant } \\
\text { Value }\end{array}$ \\
\hline $\begin{array}{l}\text { Regretion } \\
\text { Model 1 }\end{array}$ & Constanta & 1,858 & 9,590 & $\mathbf{0 , 0 0 0}$ \\
$\begin{array}{l}\text { Regretion } \\
\text { Model 2 }\end{array}$ & $\mathrm{X}_{1}$ & 0,378 & 8,507 & $\mathbf{0 , 0 0 0}$ \\
& Constanta & 3,399 & 75,738 & $\mathbf{0 , 0 0 0}$ \\
& ZX1 & 0,266 & 9,065 & $\mathbf{0 , 0 0 0}$ \\
& $\begin{array}{c}\text { ZX2 } \\
\text { Abs(ZX1 }-\end{array}$ & 0,156 & 5,447 & $\mathbf{0 , 0 0 0}$ \\
& ZX2) & & 2,431 & $\mathbf{0 , 0 1 7}$
\end{tabular}

Regretion Model 1, Value $R^{2}=0,432 ;$ F-test $=72,376$ (Sig. 0,000)

Regretion Model 2, Value $R^{2}=0,575$; F-test $=41,956$ (Sig. 0,000)

Sources: processed data, 2017

\section{CONCLUSION}

Budgetary participation has been proved to have a positive effect on budgetary slack. Budgetary slack is performed to avoid the risk of uncertainty in reaching the budget and to improve the performance of SKPD. Therefore, it should be in the form of the real employee participation and not the quasi-employee participation. The huma betang culture has been proved in moderating the effect of budgetary participation on budgetary slack. The huma betang culture applied in the community of Palangkaraya City Government will reduce the quasiparticipation in the preparation of the budget. 
This research is limited to the budget planning process in Palangkaraya City Government so that subsequent research can be conducted for the whole process of government budgeting by using Dayak Culture which diverse in Kalimantan Island.

\section{REFERENCES}

Abubakar, HM. 2016. Huma Betang dan Aktualisasi Nilai Kearifan Lokal dalam Budaya Dayak (Huma Betang and the Value Actualization of Local Wisdom in Dayak Cultural) . Humanika, Vol 1, No. 2, Juli - Desember 2016.

Andriyani, Lilik., dan Hidayati, L.A. 2010. Pengaruh Komitmen Organisasi terhadap Hubungan antara Kejelasan Sasaran Anggaran dan Partisipasi Anggaran dengan Senjangan Anggaran, Studi Kasus Pada Pemerintah Kabupaten Magelang (The Influence of Organizational Commitment to the Relationship between Clarity of Budgetary Objective and Budget Participation with Budget Slack, Case Study At Government of Magelang Regency), Thesis. University of Muhammadiyah Magelang.

Anthony, Robert. N and Vijay Govindarajan. (1998). International Edition: Ninth Edition, Management Control Systems. North America: The McGraw-Hill Companies Inc.

Dunk, Alan S. 1993. The Effect Of Budget emphasis and Information Asymmetry On The Relation Between Budgetary Participation and Slack. The Accounting Review. Vol.68. No.2. 1993:400-410

Falikhatun. 2007. Interaksi Informasi Asimetri, Budaya Organisasi, dan Group Cohesiveness dalam Hubungan Antara Partisipasi Anggaran dan Budgetary Slack: Studi Kasus pada Rumah Sakit Umum Daerah se Jawa Tengah (Information Interaction of Asymmetry, Organizational Culture, and Group Cohesiveness in Relationship between Budgetary Participation and Budgetary Slack : Case Study at Regional General Hospital throughout Central Java, Simposium Nasional Akuntansi. X. Hasanudin University, Makasar. 26-28 July 2007.

Ghozali, Imam. 2011. Aplikasi Analisis Multivariate dengan Program IBM SPSS19 (Application of Multivariate Analysis with IBM SPSS19 Program), Edisi kelima (Fifth Edition). Semarang. Badan Penerbit Universitas Diponegoro (Publisher University of diponegoro).

Govindarajan, V. 1986. Impact of Participation in The Budgetary Process on Managerial Attitudes and Performance. Universaliticand Contingency Perspective. Decision Sciences 17: 496-516.

Gubernur Kalimantan Tengah. 2008. Perda Provinsi Kalimantan Tengah No. 16 Tahun 2008 tentang Kelembagaan Adat Dayak di Kalimantan Tengah.

Hafsah. 2005. Pengaruh Asimetri Informasi dan Komitmen Organisasi terhadap Hubungan antara Partisipasi Anggaran dan Kesenjangan Anggaran. Tesis. Medan: Program Pascasarjana, Universitas Sumatera Utara

Hansen, D.R., dan M.M. Mowen. 2013.Management Accounting. Edisi Keempat. South-Western College Publishing.Mowday R., Steers, $\mathrm{R}$ dan Porter, L. 1979. The Measurement of Organizational Commitment. Journal of Vocational Behaviour. 14, pp. 224-247

Hofstede, G. (2011). Dimensionalizing Culture: The Hofstede Model. Online Readings In Psychology And Culture, Vol 2.

Ikhsan, Arfan, dan Ane, La. 2007. Pengaruh Partisipasi Anggaran terhadap Senjangan Anggaran dengan Menggunakan Lima Variabel Pemoderasi. Simposium Nasional Akuntansi X. Unhas Makassar. 26-28 Juli 2007. ASPP-02.

Jensen, M.C., and Meckling William H. 1976, Theory of the Firm: Managerial Behavior, Agency Costs, and Ownership Structure. Journal of Financial Economics, 3(4), pp:305-260.

Kencana, I. K. A. W. 2010. Pengaruh Dana Alokasi Umum dan Pendapatan Asli Daerah terhadap Belanja Pemda pada Kabupaten/Kota di Bali. Tesis. Denpasar: Universitas Udayana

Kusni Sulang. 2011. Budaya Dayak Permasalahan dan Alternatifnya, Berdiri di Kampung Halaman, Memandang Tanah Air Merangkul Dunia. Cetakan I. Banyumedia, Malang.
Lowe, E.A., dan Shaw, R.W. 1968. Analisis Biasing Manajerial: Bukti dari Proses Penyusunan Anggaran Perusahaan. Jurnal Studi Manajemen 5: 304-315.

Lukka, K.1988. Budgetary Biasing in Organization: The Theoretical Framework and Empirical Evidence. Accounting, Organizations, and Society. Vol. 13 (30: 281-301).

Maskun, Ali. 2008. Analisis Faktor Etika, Budaya Birokrasi, Tekanan Sosial, dan Kapasitas Individu terhadap Budgetary slack. Kajian Perilaku Eksekutif dalam Proses Penyusunan Anggaran di Badan Koordinator Wilayah II Jatim. Terakreditasi Dirjen Dikti 2008.

Merchant, K.A. 1981. The Design of The Corporate Budgeting System: Influence on Managerial Behavior and Budgeting Performance. The Accounting Review, Vol.56., No.4, pp.813-829.

Nasution, E.Y. 2011. Analisis Kapasitas Individu, Partisipasi Penganggaran dan Kesenjangan Anggaran pada Satuan Kerja Perangkat Daerah Kabupaten Langkat. Tesis. Medan: Sekolah Pascasarjana Universitas Sumatera Utara Medan.

Onsi, M. 1973. Factor Analysis of Behavioral Variable Affecting Budgetary slack. The Accounting Review. July:535-548.

Reysa, Annastasya. 2011. Interaksi Asimetri Informasi, Kultur Organisasi, dan Group Cohesiveness antara Partisipasi Penganggaran dan Budgetary slack di PDAM Delta Tirta Sidoarjo. Tesis. Jawa Timur: Universitas Pendidikan Nasional Veteran.

Robbins dan Judge. 2008. Perilaku Organisasi, Edisi Duabelas, Penerbit Salemba Empat : Jakarta.

Sandrya, Dewi Ni Luh Putu. 2013. Analisis Pengaruh anggaran Partisipatif Pada Budgetary slack dengan Asimetri Informasi, Komitmen Organisasi, Budaya Organisasi, dan Kapasitas Individu sebagai Variabel Moderasi (studi Kasus pada SKPD Di Kabupaten Badung, Bali. Tesis. Program Pascasarjana Universitas Udayana.

Siegel, G., dan H.R. Marconi. 1989. Behavioral Accounting. SouthWestern Publishing, Co: Cincinnati, OH, 1989.

Sudarba, I. K. 2010. Pengaruh Partisipasi Penganggaran, Komitmen Organisasi dan Ketidakpastian Lingkungan pada Senjangan Anggaran (Studi Kasus Pada Satuan Kerja Perangkat Daerah SeKabupaten Tabanan). Tesis. Denpasar: Universitas Udayana

Sugiyono. 2011. Metode Penelitian Bisnis (Pendekatan Kuantitatif, Kualitatif, dan R\&D). Cetakan ke-15. Bandung. ALFABETA.

Tjilik Riwut. 2007. Kalimantan Membangun Alam dan Kebudayaan. Cetakan II, Penyunting Nila Riwut. NR Publishing, Solo.

Wahidin Usop. 2001. Hubungan Kekerabatan pada Masyarakat Kalimantan Tengah. Himmah Jurnal Ilmiah Keagamaan dan Kemasyarakatan, Vol II, No. 23, Jan-April.

Young, S. Mark. 1985. Participative Budgeting: The Effects of Risk Aversion and Asymmetric Information on Budgetary Slack. Journal of Accounting Research, Vol. 23 No. 2 Autumn.

Yuhertiana, Indrawati. 2004. Kapasitas Individu dalam Dimensi Budaya, Keberadaan Tekanan Sosial dan Keterkaitannya dengan Budgetary slack. Wacana. Fakultas Ekonomi UPN "Veteran" Jawa Timur.

Yuwono, I.B. 1999. Pengaruh Komitmen Organisasi dan Ketidakpastian Lingkungan terhadap Hubungan antara Partisipasi Anggaran dengan Senjangan Anggaran. Jurnal Bisnis dan Akuntansi, Vol. $1: 37-55$. 